\title{
The Clash of Culture in Neil Gaiman's American Gods
}

\author{
Naya Fauzia Dzikrina*, Ahmad Munjid \\ Universitas Gadjah Mada, Indonesia \\ *Email: nayafauzia@gmail.com
}

\begin{abstract}
A B S T R A C T
This research aims to examine the portrayal of cultural clash in Neil Gaiman's novel, American Gods. More specifically, this research aims to identify what cultures are clashing and why they clash, and also to understand how the situation of cultural clash affects the lives and attitudes of the characters. This research also explores how the novel relates to cases of cultural clash happening in the current American society. This research is conducted using the framework of several sociological theories to understand the different forms of effects of cultural clash. The main issue presented in the novel is the conflict between the old gods, who represent society's traditional beliefs, and the new gods, who represent the shift of culture in modern America. This conflict symbolizes how the two ideals, tradition and modernity, are competing in the American society today. The challenges the old gods face can also be seen as a portrayal of the immigrant experience, where they experience effects of cultural clash also commonly experienced by immigrants: cultural displacement, identity crisis, and conflict. The main finding of this research is that a person or group who experiences cultural clash will face a struggle where they must compromise or negotiate their cultural identity in order to be part of their current community. This is done as a way to survive and thrive in their environment.
\end{abstract}

Keywords: conflict, cultural clash, displacement, identity, modernity, tradition.

\section{INTRODUCTION}

Cultural clash is any form of disagreement or conflict resulting from the interaction between two or more different cultures. This can be individual experiences or nation-wide conflicts. For ceturies, this has been one of the main issues that have shaped the world we know. It has been the cause of wars and tragedies, but it has also helped shape new communities and cultures. In today's world, cultural clash is one of the most frequent problems to arise, since cross country migrations and globalization are at their peak.

The effects of cultural clash have a broad spectrum. It ranges from things only an individual experiences to nation scale wars. It may be related to micro things such as how a person feels estranged in a new community or to larger cases such as racism and religious intolerance.
America has long since-and still is-one of the biggest countries with a cultural mix. Its founding history can be traced from immigrants resettling from all over the world. Almost all of America's people come from immigrants, and we can still see the effect of this today. Therefore, it is natural that cultural issues are familiar in America's society and history.

The novel American Gods by British author Neil Gaiman uses cultural problems as one of its main themes. The story is about ancient gods and goddesses from different cultures around the world in America. They are as multi-cultured as the people of America itself. The novel's themes deal with the issues of culture, identity, and the conflict that arises from those two aspects. It does so by portraying the cultural situation of America, which is one of the most culturally diverse countries in the world. The story also focuses a lot 
on the immigrant experience. Other than the experiences of the old gods, who consider themselves immigrants, the novel also provides short stories and histories of different groups of immigrants.

American Gods is not the only novel focusing on gods and goddesses from mythology living in the real world. Yet, it is one of the rare novels to have those gods as symbols of society today. American Gods offers an insight of the current America to the readers: its landscape, people, history, and cultures. Reading and understanding American Gods provides a deeper way of understanding cultural issues that have shaped America, and still relevant in its society today.

This award-winning novel has attracted scholars to investigate it. For example, Hill (2005) investigated the novel in answer to the following questions: what does it mean to be American? and how does an outsider view the American culture? He found that the novel polarizes the American culture by time, into two different periods: the past and the present. He concludes that outsiders view that American culture is always changing and criticizes that America now is not as great as it used to be.

Another research on American Gods was done by Firman (2010). She examined the ways in which the fantasy genre is ideally positioned for discussing social issues, such as invisibility and liminality. She argues that the features of the fantasy genre that Neil Gaiman uses in his stories are used to present a different perspective on reality.

Muller (2015) explored how Neil Gaiman presented the female gender in his novel. She discussed how the gender myths of the American society were questioned through the novel. In American Gods, common gender roles and expectations were confronted. Women were presented with traits that defied the common expectation in society.

Rata (2015) investigated the intertextual references in the novel as it is renowned for its extensive intertextuality. She also examined the role and importance of those intertextual references in the creation of the American identity, and its cultural representation in Gaiman's novel, by examining the types, functions, and effects of intertextuality. She concluded that

In American Gods Gaiman created a rich intertextual web of references, which creates a complex image of America and its identity. Gaiman's America is a pastiche of discordant individual voices representing different cultures, values and nationalities, and their corresponding idiosyncrasies, combined into a representtation of modern America, as a multicultural, polyethnic country, marked by its own strengths and weaknesses; yet, incredibly complex and rich in its diversity (p. 111).

However, none has specifically examined cultural clashes in the novel. Therefore, this research focuses cultural clashes in the novel in an attempt to obtain a new perspective and insight for a better understanding of the novel and the issues it presents. In particular, it attempts to investigate what cultures are involved in the clash and for what reasons, and to examine how the clashes affect the characters who experience them, and how the clashes relate to issues happening in America.

\section{METHODS}

The primary data source of the research was the novel American Gods by Neil Gaiman (2002). The data for this research were events of cultural clash experienced by the characters, which are mainly represented by the characters of mythical gods. The data forms are narratives or dialogues which are related to those events.

Secondary data sources were also used in this research. They include articles, news, and journals about cultural issues that happen to immigrants in the United States. Also, references dealing with mythologies from different cultures such as Norse, Egyptian, and Slovakian mythologies mentioned in the work were also consulted to fully understand the characters and identify the cultural clashes that were found in the novel. 
Close reading was performed to gain a comprehensive understanding of the novel, and how the issue is presented in the novel. Next, the work was analyzed to identify events of cultural clashes that happen in the novel. This was done by listing any narratives, dialogues, or events that have the elements of culture.

After identifying and listing the different occurrences of cultural clashes in the novel, these data were then analyzed to identify what cultures are clashing and the reasons behind the clash or clashes. The effects of this cultural clash were categorized into three types: cultural displacement, identity crisis, and conflict. Each of these were analyzed separately to gain a full understanding of its causes.

To understand the phenomenon of cultural displacement, the two major groups of culture (contemporary and traditional) were analyzed and contrasted with each other to identify the elements that clash. The elements were identified based on the definition of culture given by Matsumoto \& Juang (2012).

Next, Dubois \& Edward"s concept of double consciousness was used to explain the internal clash within the individual, which is their experience in facing identity crisis. This analysis was done by first identifying the characters that experience identity crisis, then understanding the personalities and traits of these characters. The analysis focused on the traits of the characters that are different or have changed from before and after the presence of the main problem in the novel. Doing so revealed what and how the clash is happening within the individual. Last, conflict theory was used to explain the occurrence of conflicts, the forms and the cause.

Upon completion of the intrinsic analysis of the novel, secondary data of news and articles of cultural clash happening in America were used to relate the novel to real situations happening in America. These actual examples of cultural clash showed how the novel reflects the actual American society.

Other secondary data that helped explain the elements of culture and why they clash consist of: first, references of the different cultural backgrounds that are mentioned in the novel, focusing on how the old gods are represented in their original mythology. Second, information of the history of America, especially the formation of America as a land of immigrants. And last, news or articles describing the lifestyle and also situation of immigrants living in America during the time the novel was written (early 21st century), to give a more complete understanding of the context of the issue that is discussed.

\section{THEORETICAL FRAMEWORK}

Because the work is viewed as a social critique to real life society, it is important to relate the work to its actual setting. Therefore, sociological approach is used to analyse this work. According to Scott (1966, p. 123),

\begin{abstract}
Sociological approach starts with conviction that art's relations to society are vitally important, and that the investigation of these relationships may organize and deepen one's aesthetics response to a work of art. Art is not created in vacuum; it is the work not simply of a person, but of an author fixed in time and space, answering to a community of which he is an important, because articulate part. The sociological approach, therefore, is interested in understanding the social milieu and the extent to which and manner in which the artist responds to it.
\end{abstract}

To understand which form of culture that was specifically analyzed from the novel, the term 'culture' in this research is defined following Matsumoto \& Juang (2012, p. 16) as "the set of attitudes, values, beliefs, and behaviours shared by a group of people, but different for each individual, communicated from one generation to the next." From this definition, the research examines aspects of culture involving the values, beliefs, and behavior of an individual or group within the society.

One of the main themes of the book is about the immigrant experience, the immigrants being the gods themselves and also the people who brought them there. The immigrant experience is 
most commonly discussed under the concept of 'diaspora'. According to Ashcroft, Griffiths \& Tiffin (2000, p. 61), diaspora means "the voluntary or forcible movement of peoples from their homelands into new regions." This definition well describes the characters of the novel. Also, the concept of diaspora is essential to understand the dynamics of the American society.

There are several forms of effects of cultural clash found in the novel, three of which are: cultural displacement, identity crisis, and conflict.

In a cultural context, Bammer (1994, p. 9) defines displacement as "the separation of people from their native culture, through physical dislocation (as refugees, immigrants, migrants, exiles, or expatriates) or the colonizing imposition of a foreign culture." Cultural displacement is a phenomenon that occurs when a person, or a group of people, is 'placed' within a cultural environment that is different from their own. The phenomenon of cultural displacement can develop into other issues: identity crisis, which is experienced as an individual, and conflicts which are experienced as a group.

One of the key features of the immigrant experience is the feeling of having multiple identities, a situation where an individual feels being a part-and not being a part-of more than one society or culture. A person experiencing this feeling can be said to be experiencing identity crisis. This experience of confusion creates an element of conflict within the individual, as they struggle to reconcile their whole identity. The analysis of this type of conflict will be based on Dubois \& Edward's concept (2007) of 'double consciousness'. This concept refers to a state of a person who lives with two conflicting identities that cannot be entirely merged together. Dubois \& Edward (2007, p. 8) describe this feeling as follows:

It is a peculiar sensation, this double consciousness, this sense of always looking at one self through the eyes of others ... One ever feels his two-ness; two souls, two thoughts, two unreconciled strivings; two warring ideals in a dark body.
The final form of cultural clash effect is conflict. The analysis of conflicts happening in the novel are based on a specific application of the general sociological conflict theory, which is used to analyze ethnic conflicts. Oberschall (2010, p. 180) argues that "Identity Politics (IP), also known as Symbolic Politics (...), holds that in multiethnic societies, the root cause of ethnic conflict is a threatened change in the prevailing ethnic hierarchy of dominance and subordination."

This theory examines the roots of ethnic conflicts. Applied to the novel, the different 'ethnic groups' include the groups of old gods and new gods. This conflict theory also helps to understand the nature of the relations between the two opposing groups identified in the novel, and explain why conflicts occur between them.

\section{RESULTS AND DISCUSSION}

To begin the discussion, it is essential to establish what forms of culture is discussed in this paper. As mentioned earlier, Matsumoto \& Juang (2012, p. 16) define culture as "the set of attitudes, values, beliefs, and behaviours shared by a group of people, but different for each individual, communicated from one generation to the next."

This definition is appropriately relevant to the novel American Gods. In the novel, the forms of culture highlighted are those relating to traditions and beliefs. The main characters of the story are gods and goddesses. These gods are manifestations of what their people believe and rely upon. The more people believe and commit actions of belief, the stronger the gods are. Reversely, the less people believe the weaker the gods become, and if forgotten altogether, they will cease to exist.

\section{The Clash of Cultures}

The story uses the characters of gods as symbols to represent these forms of culture existing in society: belief and attitude. The old gods symbolize the people of America who used to rely on their beliefs and the traditions they were brought up with. While the new gods symbolize the fading of belief, which is replaced by reliance on modern technologies. In the novel, these are the two main forces that collide. By looking at the 
changes in the American society in the last few decades, the competing positions of the old gods and new gods symbolize a shift in American culture: from a traditional and religious society towards a more modern yet secular society; while the battle between the gods symbolize how these two different ideals are clashing within the current society.

The old gods come from ancient myths and legends in which people believed hundreds of years ago. The society in which they emerged in was very different from the society they live in today. Most of the old American gods were brought to America during the early periods of immigration. The society that lived during that time were mostly communal, nomadic, and had strong traditions which they held to with pride.

Illustrations of the early stages of American resettlement are given as short interludes in the novel, entitled 'Coming to America'. One of the stories is about the Vikings who found the 'new land' in A.D. 813. It describes how the Vikings had sailed long and hard in their world exploration. They were tough men, but whenever they had any trouble, they would pray and call upon the powers of the All-Father to bring them safely back to shore. This shore they landed in would one day become America. At night, they would gather to sing songs and exchange tales of the greatness of the All-Father. Finally, to show their gratitude towards their god, they captured a wandering scraeling, and hung him from a tree as sacrifice, an imitation of how Odin had sacrificed himself to gain his powers. It was through this act of strong belief did Odin establish his existence in the new land.

Those forms of rituals and belief practices originated from cultures and traditions that developed since ancient times. From the novel, it can be understood that these rituals were still performed by the people who first came to America. However, in the centuries that followed, it soon becomes apparent that this situation did not continue for long.

In the past several decades, specifically after the end of World War II, information technology and transportation have developed rapidly, leading to changes in lifestyle all over the world.
In America, one of the indicators of this change is the noticeable shift in religious attitudes that is currently taking place. According to some reports (America's changing religious landscape, 2015; Reiss, 2015; U.S. Public becoming less religious, 2015), religiosity in America is experiencing a decline. People are moving away from traditional religious practices and prefer alternative spiritual enhancements that are not tied to a certain religion. This trend is especially true among the younger generation of America. This can be witnessed through the decline in attendance in places of worship, such as the church and synagogue, and fewer people who claim to be affiliated to a certain religion.

This reality is the main issue portrayed in American Gods. Many people no longer subscribe to a specific religion, and a significant number of those who still do no longer practice rituals of belief. Also, people are becoming more individualistic, so religious rituals and rites that are usually performed in groups are performed less and less. In American Gods, this phenomenon is the cause of the gods' decline of power and influence, which forces them to struggle for survival.

One explanation for this phenomenon is that people have moved their reliance away from something abstract, such as the imagination of gods, towards something more concrete, such as technology and science. In the novel, the new gods portray this reality. Unlike the old gods who came from different places across the globe, the new gods were 'born and raised' in America. They come to existence from people's belief, dependence, and addiction towards the peaks of $21^{\text {st }}$ century lifestyle: the internet, media, military, free market, and many other things.

The problem found in the novel is not one which can be easily reconciled. The cultures that clash are opposing each other (tradition and modernity, religiosity and secularity), which makes it challenging for both ideals to exist at the same time and place.

\section{The Effects of Cultural Clash}

From the different occurrences that involve cultural clash identified in the novel, it becomes 
apparent that the challenges which the characters experience mimic those of immigrants. The incidents that the characters face are actually the result or effects of the cultural clash happening, and this is apparent in the novel. Therefore, the essential theme of the novel and this paper is about the American identity through the immigrant experience.

From this point of view, the incidents that are the effects of cultural clash can be divided into three main aspects which are experienced by most of the characters and also by real life immigrants: cultural displacement, identity crisis, and conflict. The clash of cultures results in the experience of being culturally displaced which then develops into identity crisis. Finally, the clash creates a situation which threatens the survival of the characters (the old gods), which therefore pushes them to take action that results in conflict.

\section{Cultural Displacement}

As mentioned earlier, Bammer (1994, p. 9) defines displacement as "the separation of people from their native culture". This is a phenomenon which is experienced by the majority of immigrants or anyone moving to a new environment, and is familiar to the people of America.

In the novel American Gods, the old gods are the ones who feel that they do not belong in the land of America, and this has been something they were struggling with since their early existence in America. The situation that their 'new land' is not welcoming to gods is quickly realized and acknowledged by the old gods. Jacquel, also known as Anubis, the Egyptian god of the dead, says that "... we lost this particular battle when we came to this green land one hundred years ago or a thousand or ten thousand. We arrived and America just didn't care that we'd arrive" (Gaiman, 2002, p. 208). This theme is also repeated several times in the novel, reemphasized by each character. For example, the buffalo man says "This is not a land for gods ... This is a land of dreams and fire" (Gaiman, 2002, pp. 245-246).

The reason they feel that way is because the people who arrived in America, and the society that developed from that were very unlike their 'native' culture. What developed was a society that did not care much for traditions, a society that chose to focus on bettering their welfare through materialistic means.

The setting of the novel takes place centuries after the gods' first arrival. Life has not developed well for them. Most of the old gods live a simple life at the edges of society, making their homes in small, shabby apartments unnoticed by the people around them. Being unnoticed or ignored is also a form of displacement. People who belong within a society will feel able to interact and integrate with other members of their society. Not being able to do so further proves that the old gods have no place in American society.

The meagre lifestyle of the old gods mimics real lives of old immigrants in America. Farrell (2016) gives insight on this topic. Most of the elderly immigrants can no longer work and rely on social aid or their children to live. In society, they are often ignored. Farrell (2016) writes: "They seem almost invisible to the wider society". Conditions are especially hard for those who have spent all their lives working in low-waged jobs that do not offer retirement benefits. Bee Yang, an elderly Lao immigrant describes his life in America as being 'lonely' and 'difficult'. Jose Arrieta, an elder special access outreach specialist, states that 'vulnerability' and 'loneliness' are the major concerns for the elderly who are unnoticed by society. Life is tough for these immigrants because they feel isolated and they have to rely on a society that does not need or care for them. The article concludes that the most important step to take is to integrate the elderly back into society (Farrell, 2016).

In American Gods, the gods and cultures that have died out went through similar experiences of society neglect as the elderly immigrants. The cultures that disappeared are those that have failed to remain relevant with the ever-changing society of America, so they are left behind. Keeping up with change has become something that is increasingly challenging to do. The world, including America, has been rapidly developing ever since the industrial revolution. Many traditions that have been practiced for 
centuries are suddenly struggling to stay relevant in today's society.

In the novel, the conflict begins when the new gods start gaining more power, and that they are against the old gods. What is happening is that the new gods are unwelcoming the old gods because they feel that they are a group to compete against, when actually, the old gods by themselves are already struggling with their current situation.

A most recent example of cases of cultural displacement is a phenomenon known as 'The Trump Effect', which took place during the campaign of President Donald Trump at the end of 2016 (Costello, 2016). 'The Trump Effect' is a phrase coined by researchers from the Southern Poverty Law Center (SPLC) who, in 2016, conducted a survey to examine the effect of 2016's presidential campaign on school children. The survey was done by sending questionnaires to 2000 teachers across the country from every level of education. The survey found that the campaign had produced a widespread negative effect in schools, indicated by increase of anxiety and fear among students of color and ethnic or religious minorities, caused by the news they hear and from being bullied by their peers. "Teachers have noted an increase in bullying, harassment and intimidation of students whose races, religions or nationalities have been the verbal targets of candidates on the campaign trail" (Costello, 2016, p. 4).

Because of this, teachers have been struggling to keep all their students feeling safe at school. Most teachers have also been reluctant to teach about the elections in class since it has become much too stressful for the marginalized students. Many students are also struggling to understand the situation of their country. They have been taught that America is a land of immigrants where everyone is equal, but their reality does not match. "Many immigrant students feel that "they don't belong here" and they have "no value" to the country" (Costello, 2016, p. 9).

The feeling of not belonging and being rejected by a certain society are common experiences for people who are culturally displaced. The situation of being culturally displaced is the main issue for immigrants who struggle to be a part of their new society. Cultural displacement can lead to other problems, both within an individual and also inter-group conflicts.

\section{Identity Crisis}

Identity crisis can be developed from being culturally displaced, since a person naturally relates his or her identity to where they belong. The experience of identity crisis is common among immigrants. To fully become part of another society, a person might have to compromise or change parts of their identity to suit the majority. In the end, some might choose to hold on to their origins while some might prefer to adopt a new culture. It is this process of struggling to reconcile their different senses of self that turns into the experience of identity crisis.

Dubois \& Edward' concept of doubleconsciousness explores the condition of being a part of two cultures, but not being fully accepting or being accepted by either of them. It explores the feeling of being stuck between two cultures that are often experienced by people of ethnic or religious minority. Going back and forth between two different cultures or identity will create the sense of uncertainty and confusion within a person. In American Gods, this condition is depicted mostly by the old gods. Most of them struggle to survive by being an average American citizen while still holding on to aspects of their true self as much as they can afford. Throughout the novel, most gods make their appearance as a normal person, but in several unique situations a short glimpse of the gods' true nature is revealed.

During the meeting of the gods at the carousel, Shadow gets a glimpse of the true nature of all the gods that gathered, including Czernobog, the Slavic god of death.

... he also saw a squat black thing, darker than darkness that surrounded them, its eyes two burning coals; and he saw a prince, with long flowing black hair and a long black moustache, blood on his hands and his face (Gaiman, 2002, p. 132). 
While the description of the true form of Czernobog is majestic and terrifying, his reincarnation as a person is not. He is an oldgrumpy man who lives in a small apartment in Chicago. "The man in the dusty bathrobe was short, with iron-gray hair and craggy features. He wore gray pinstripe pants, shiny from age, and slippers" (Gaiman, 2002, p. 75). In another instance, before seeing Czernobog's true form, Shadow saw him as "a gray-haired old EasernEuropean immigrant, with a shabby raincoat and one iron-colored tooth" (Gaiman, 2002, p. 132).

The case of identity crisis in the story goes beyond appearance. Some characters experience it in a more challenging way. One of the first characters to be introduced in the novel is Bilquis. Bilquis is actually the Queen of Sheba, a very well-known queen long ago in the Middle East. As a queen, she was renowned for her beauty and power. However, in America, her situation is pitiful. Bilquis mainly gets her power from being worshipped, in whatever way. In her new land, nobody knows or cares about her, and this affects her deeply. In order to get the worship she needs, she becomes a prostitute in Los Angles. She chooses her clients carefully, only choosing those who she knows will do as she says and worship her.

Bilquis is one of the extreme examples of what an old god will do to survive. She is unable to let go of her past self that feels powerful through being worshipped, even though she does not like what she is doing, and feels conflicted with her identity. She says that there is "...nothing holy left in her profession. Not anymore" (Gaiman, 2002, p. 373). But, with the circumstances, she feels that she has no choice in order to get what she needs. The way Bilquis sees herself is different than how others see her; no one is aware that Bilquis is a powerful being. Bilquis realizes this fact and behaves accordingly to people's expectations in order to survive.

A phenomenon that portrays this dilemma is one happening within the society of 'Americanized Muslims'. Particularly, after the 9/11incident, Muslims in America have experienced sharper and more frequent forms of discrimination and prejudice. Muslims are seen as threats, terrorists, people who condemn the American culture. Clearly, this is a view that does not resonate with the majority of Muslims and creates a challenging life situation for them. In response to this, some groups of Muslims in America attempt to change society's views by practicing a more 'Americanized' version of Islam, even when it is critiqued as conflicting with the very teachings of Islam. Skerry (2013) describes this situation as follows:

Since 9/11, Muslim leaders have shown a remarkable-and largely unnoted, or disbelieved-willingness to adapt to America. Indeed, these leaders have been busily reconstructing an anodyne version of Islam that conforms to the American civil religion. Yet once again, they are leading the faithful into various double-binds.

However, Kirby (2015) criticizes this movement by saying that this version of Islam is targeted for "non-Muslim audiences". This phenomenon comes from the case of doubleconciousness, in which Muslims struggle to connect their religious and national identities.

An important aspect of experiencing identity crisis is the questioning of self-worth. This is most evident in Wednesday, since he used to be one of the most powerful gods. With his current situation, he has faced two different situations of life, which leads him to grow doubts in the importance of his existence; he questions whether or not it is a good thing to be a god. This scene indicates that the old gods are feeling a loss of purpose. Long ago, people believed them because people needed them, but the situation has turned to be them needing the people.

"I'm a has-been. Who the fuck cares about me?"

Shadow said softly, "You're a god."

Wednesday looked at him sharply. He seemed to be about to say something, and then he slumped back in his seat, and looked down at the menu, and said, "So?"

"It's a good thing to be god," said Shadow. 
"Is it?" asked Wednesday, and this time is was Shadow who looked away (Gaiman, 2002, p. 360).

Through the portrayal of the old gods, the novel presents a case of cultural clash and identity crisis which is quite clear. It is about people who originally have a strong sense of personal identity but is faced with a society that rejects them, and so they have to try and reconcile their identity with their reality. From another perspective, it is also about people who used to have purpose and high value in their abilities, but the change of circumstances has left them without any.

This is a common case of identity confusion among immigrants. A case example that mimics the characters of the novel is the stories of American immigrant wives. The rapid development of the technology industry pushes companies in America to hire skilled workers from other countries, mostly from Asian countries such as India, Korea, and China. The people they hire are well-educated professionals in their field who mostly consists of men. The wives of these men follow their husbands to America, but with very different circumstances. While the working men are granted H1B visas (for professional workers), their wives are only granted $\mathrm{H} 4$ visas, which does not permit them to work.

The women of this group of immigrants are also well-educated and skilled, and they have had their own careers in their native countries. However, when they arrive in America, they find themselves in a situation where they are helpless. They not only cannot work, but their daily lives are limited by language and cultural barriers. A lot of these women are reported to suffer from anxiety, from being unable to work and losing purpose of their life, and also depression, from being lonely and feeling isolated. During the first months, or even years, of staying in America, they struggle to get through their daily lives and be part of the community.

As reported by Thompson (2015), Amy Bhatt, an assistant professor of gender and women's studies at the University of Maryland, says of these immigrant wives: "They are a highly educated group of women, trained in fields like engineering and computer science, coming to what they think is the land of opportunity and equality. They come here and they're relegated to the status of being a housewife. For some, there's real anxiety and depression". Most of the women also expressed disappointment with their current situation, and compares how different their life used to be.

A sense of purpose and value plays a big role in the shaping of one's identity. The experiences of the immigrant women above are much like the American gods; both groups are forced to a change in situation that results in them losing their selfvalue and life purpose. In their previous communities, both groups felt important and more powerful, or independent. They are viewed by themselves and society as something valuable. In their new community, they are not able to assume their past roles. This leaves them struggling to get through their daily lives. As reported by Thompson (2015), Mariane Maccarini, a Brazilian immigrant, says: "I lost my identity ... I'm trying to get it back."

The concept of 'home', cultural displacement, and identity are all interrelated. The feeling of being 'home' is usually related to the feeling of belonging to a certain place, people, or cultural group. It is this that immigrants lack. Because they are culturally displaced, they feel they do not belong within the community, and thus experience identity crisis.

\section{Conflict}

The novel's main conflict is the building tension between the old gods and the new gods. Symbolically, the conflict represents real life competition between contemporary lifestyle and tradition; a phenomenon which can be seen happening across the globe. But as characters in the novel, these two groups of gods have specific purposes which cause conflict between them.

According to the general conflict theory, conflict in a society occurs when the groups within the society are all struggling for control over limited resources. This statement is apparent in the novel, where the different groups are the old gods and the new gods, while the limited resource is the influence over people's lives. As mentioned earlier, Oberschall (2010, p. 180) 
argues that "Identity Politics (IP), also known as Symbolic Politics (...), holds that in multiethnic societies, the root cause of ethnic conflict is a threatened change in the prevailing ethnic hierarchy of dominance and subordination." What is highlighted in Obershcall's statement is that the cause of conflict is a change that threatens to alter the existing hierarchy between the dominant and the subordinate group.

In American Gods, the conflict arises when the new gods start to gain more power that threatens the existence of the old gods. Following the theory, the group of old gods can be seen as the dominant group, since they have held power longer. The new gods, as the subordinate group, attempt to overpower the old gods to gain full control of America. The motive of the new gods is most strongly emphasized in this statement from Technical Boy which he says to Bilquis before torturing her and then killing her,

I want a clean world. I want to own tomorrow. I want evolution, devolution, and revolution. I want to move our kind from the fringes of the slipstream to the higher ground of the mainstream. You people are underground. That's wrong. We need to take the spotlight and shine. Front and center (Gaiman, 2002, p. 377)

Unfortunately, harassments and killings such as what is experienced by Bilquis is also true in the American society.

The latest annual statistical report from the FBI (Latest hate crime statistics released: Annual report sheds light on serious issue, 2016) shows that the number of hate crimes in America has increased significantly in the course of one year, 2014 to 2015. The target of these hate crimes are mostly Muslims, with an increase of $67 \%$, followed by Jewish and Mexicans. The FBI has further analysed the report by categorizing the crimes depending on the type of bias, the result of 2015 as follows: out of 5,818 hate incidents, crimes were prompted by race/ethnicity/ancestry bias were the most common (59.2\%), followed by religious bias (19.7\%), and sexual orientation bias $(17.7 \%)$, with gender identity $(1.7 \%)$, disability
$(1.2 \%)$, and gender bias $(0.4 \%)$ completing the percentage.

The battle of the American gods were between a group who refused 'immigrants', the new gods, and a group fighting for their rights to exist in the country, the old gods. Riots involving issues of immigration and cultural clashes have also happened in America.

The Ku Klux Klan is an infamous extremist movement in America that has existed since mid$19^{\text {th }}$ century, who, among its missions, advocates white supremacy and anti-immigration. The Southern Poverty Law Center (Costello, 2016) estimates that the third, the group currently existing, has approximately 5,000 members across the country. In February 2016, as Queally (2016) reported, the KKK held a rally in Anaheim, California, which ended in three people stabbed and thirteen arrested. The rally was immediately blocked by protesters against the KKK, which started the fighting. Witnesses report that members of the KKK used sharp ended flag poles to wound the protesters who were in their way. The basic issue of the riot in Anaheim can be said to be similar with the battle of the American gods; a group who is against immigration fights with a group who defends the rights of immigrants to stay in America.

The main idea is that each group has existing fears and worries towards their situation and who they see as the opposing side, which is a potential for actual conflict. Other narratives of cultural conflict is also told through the short interludes in the novel. The first 'Coming to America' story which tells about how Odin establishes his existence in America also describes a war between the natives and the newcomers.

The scraeling war party fell upon them at night: five hundred men to thirty. They climbed the wall, and over the following seven days, they killed each of the thirty men, in thirty different ways. And the sailors were forgotten, by history and their people. The wall they tore down, the war party, and the village they burned. The longboat, upside down and pulled 
high on the shingle, they also burned, hoping that the pale strangers had but one boat, and that by burning it they were ensuring that no other Northmen would come to their shores (Gaiman, 2002, p. 69).

The case of conflict above shows conflict that happened because of distrust from the natives towards the newcomers. The trigger of the war was the scraeling that the Northmen had captured and killed as a sacrifice to Odin. The other scraeling people might then see the Northmen as dangerous people who would kill and abuse them. Seeing how different the newcomers were from themselves could also have caused the natives, to worry that these men might force them to change their way of life. They wanted to ensure that no more new people would arrive in their lands.

The conflicts happening in American Gods all surround the issue of cultural clash. These conflicts occur not only because the cultures had irreconcilable differences with one another, but more importantly, because each group viewed the others as threats. The threats may be towards a group's way of life or sustainability. The feeling of being threatened is the main thing that pushes people towards committing acts of violence. This is apparent both in the novel, and in the actual American society.

\section{CONCLUSION}

Since the first colonialists arrived on its lands in the $15^{\text {th }}$ century, America has been an ever changing nation. Being 'the land of immigrants', its history and society is diverse and dynamic; influenced by the many different cultures that interact with each other. Following the end of World War II was a period when the development of technology and transportation were at its peak, leading to an even more rapid change within America's society, shaped by cultural interactions. Parts of these interactions have resulted in a positive outcome, in which the different cultures are able to coexist peacefully. However, other parts result in negative outcomes, where these cultures clash and create tension and conflict within the society.
Neil Gaiman, through American Gods, has attempted to portray several key issues that relate to the negative aspects of cultural interactions; the immigrant experience and the effects of cultural clash that takes place. The main conflict in the novel is the clash between the old gods and the new gods which symbolizes a shift from tradition and religion towards modernity and secularity in America's society, and how the two ideals compete with each other. These are the elements of culture that are clashing. Since these elements are opposing each other, it is challenging to create a situation where both ideals can coexist. This clash affects the characters in many ways, such as their life situations, sense of identity, and attitudes. The novel depicts three main effects of cultural clash: cultural displacement, identity crisis, and conflict.

Cultural displacement happens when a person moves into a cultural environment that is different from their own. The old gods experience cultural displacement as they struggle to find their place within their current environment. The old gods come from a culture where the community is strong and holds their traditions and beliefs firmly. However, America does not have this trait. Unlike other nations which were built upon centuries, even millennia of history, America is a relatively new nation whose society experiences change rapidly. The current society of America is one that is shifting towards modernity and secularism, which is noticeable from the significant number of Americans, especially in the younger generation, who tend to move away from tradition and established religious practices. Moreover, the emergence of the new gods further threatens the old gods' position in the society, thus, the old gods feel they no longer belong in America. The effect of this displacement is that the gods lose their power and will eventually cease to exist.

Identity crisis is an issue developed from initially feeling displaced. Being displaced affects a person by forcing them to compromise parts of their identity to fit in better with their current environment, or even, completely lose their former identity altogether. The most prominent form of identity crisis in the novel is the struggle to merge two separate identities, an experience 
known as double-conciousness. The old gods experience identity crisis because they are forced to live the lives of powerless American citizens, but they are not able to let go of their actual selves as powerful gods. The way they view themselves is different from how society views them. Furthermore, they lack the factors that build their sense of identity: they are not welcomed by their society and they can no longer fulfil the purpose of their existence.

Conflict happens when two groups or more are struggling for power and dominance over the same limited resources. Feeling threatened is what further pushes people to take action which deepens the conflict. In the novel, the old gods and the new gods are fighting for the influence of people's belief. Each side also feels threatened by the existence of the other. The new gods are doing so to further ensure their position as the ruling gods of America, while the old gods are simply fighting for their survival. Since these two groups of gods represent opposing ideals, there is no option of situation where both sides can benefit at once.

These effects of cultural clash relate to actual situations in America where many immigrants struggle with their process of assimilating into their new environment. Like the old gods, each immigrant to some degree will experience displacement when they face the American society which might be very different from their own. Although America is founded on the basis of freedom and equality, oftentimes discrimination and racism still influence the people's attitudes, especially when facing a minority group they find different or threatening. The immigrants who find difficulties in overcoming the feeling of being displaced might experience identity crisis as they question their belonging and position in the American society. Conflict arises when a certain group feels threatened by the other and takes negative action to overcome that threat.

The interaction of different cultures in a society that continues to change and develop is challenging. Even more so, when different interests related to dominance and livelihood are involved in the process. This situation forces the people who experience this (in this case, immigrants) to struggle and negotiate their options to reach a condition that will benefit them the most. In the context of culture and identity, this means a person will often have to compromise aspects of his/her culture and identity to assimilate with their society to increase their chances of thriving within their current community. To which degree a person is willing to make sacrifices and adjustments is a question each person has to deal with. Those who fail to do so will experience hardships that can obstruct them from progressing or even surviving in their environment.

\section{REFERENCES}

America's changing religious landscape. (2015). In Pew Research Center: Religion \& Public Life Project. Retrieved May 3, 2017, from http://www.pewforum.org/2015/05/12/ americas-changing-religious-landscape/.

Ashcroft, B., Griffiths, G. \& Tiffin, H. (Eds.). (2000). Postcolonial studies: The key concepts. London: Routledge.

Bammer, A. (1994). Displacements: Cultural identities in question. Bloomington: Indiana University Press.

Costello, M. (2016). Teaching the 2016 Election. The Trump effect: The impact of the presidential campaign on our nation's schools. Southern Poverty Law Center. Retrieved from https:/www.splcenter.org/ sites/default/files/splc_the_trump_effect.pdf.

Du Bois, W. E. B. \& Edwards, B. H. (2007). The souls of black folk: Oxford world's classics. Oxford: Oxford University Press.

Farrell, C. (2016). The painful struggles of America's older immigrants. In Forbes. Retrieved May 8, 2017, from https://www.forbes.com/sites/nextavenue/20 16/12/12/the-painful-struggles-of-americasolder-immigrants/\#6628d54a39d9.

Firman, C.L. (2010). Fantasy Making the invisible visible: Liminality in Neil Gaiman's Neverwhere and American Gods. Unpublished Master's Thesis. Lewisburg, PA: Bucknell University. 
Gaiman, N. (2002). American Gods. New York: HarperTorch.

Hill, M. (2005). Neil Gaiman's American Gods. An outsiders critique of American culture. Unpublished Master's Thesis. New Orleans : University of New Orleans.

Kirby, Stephen M. Why Americanized Muslim reformers are failing. Frontpage Mag. Frontpage Mag, 12 Nov. 2015. Web. 18 June 2017.

Latest hate crime statistics released: Annual report sheds light on serious issue. (2016). In $F B I$ News. Retrieved May 8, 2017, from https://www.fbi.gov/news/stories/2015hate-crime-statistics-released.

Matsumoto, D. R. \& Juang, L. P. (2012). Culture and psychology (5 $5^{\text {th }}$ ed.). Belmont, CA: Wadsworth Cengage Learning.

Muller, M.R. (2015). Gender myths in Neil Gaiman's American Gods. In The Artifice. Retrieved from https://the-artifice.com/neilgaiman-american-gods-gender-myths/.

Oberschall, A. (2010). Conflict theory. In K. T. Leicht \& J. C. Jenkins, Handbook of politics: State and society in global perspective. New York: Springer, 177-194.

Queally, J. (2016). "Ku Klux Klan Rally in Anaheim Erupts in Violence; 3 Are Stabbed and 13 Arrested." In Los Angeles Times. Retrieved May 8, 2017, from https://www.latimes.com/local/lanow/lame-ln-klan-rally-in-anaheim-erupts-inviolence-one-man-stabbed-20160227story.html.
Rata, I. (2015). The role of intertextuality in Neil Gaiman's American Gods. Cultural Intertexts 3, 103-112.

Reiss, S. (2015). Four reasons for decline of religion." In The Huffington Post. Retrieved May 3, 2017, from https://www.huffingtonpost.com/stevenreiss/four-reasons-for-decline_b_8778968.html.

Scott, W. S. (1966). Five approaches to literary criticism. New Jersey: Prentice Hall.

Skerry, P. (2013). Problems of the second generation: To be young, Muslim, and American." In Brookings. Retrieved June 18, 2017, from https://www.brookings.edu/articles/problem s-of-the-second-generation-to-be-youngmuslim-and-american/.

Thompson, L. (2015). Identity crisis: Wives of immigrant tech workers struggle to find purpose. In The Seattle Times. Retrieved May 8, 2017, from https://www.seattletimes. com/pacific-nw-magazine/while-theirhusbands-work-immigrant-wives-oftenstruggle-in-this-new-land/.

U.S. public becoming less religious. (2015). In Pew Research Center: Religion \& Public Life Project. Retrieved May 3, 2017, from http://www.pewforum.org/2015/11/03/u-spublic-becoming-less-religious/. 